\title{
A Review of the Strategies Adopted by Some Poor Nations to Alleviate Poverty
}

\section{Emmanuel John Kaka}

\author{
School of Economics, Finance and Banking, College of Business, Universiti Utara Malaysia, Sintok, Malaysia. \\ Youngkaka2002@yahoo.co.uk \\ Sadeeq Launi \\ Department of public administration, Federal Polytechnic Bauchi, Nigeria \\ sadqlauni@yahoo.com
}

Doi:10.5901/mjss.2014.v5n27p318

\section{Abstract}

Being poor is a situation of having to live in inadequacy, lack, scarcity, destitution and deficiency of economic, political and social resources. Poverty kills the moral of the people, it destroys hope and happiness and it creates resentments and envy for the rich. When people do not get what they desire to make them comfortable in life, it's like the best part of them have been taken away. Poverty is affecting relationships within the families must especially the relationship between man and women. Many lose their self-esteem and sense of personal competence. Child abuse and prostitution are outcome of poverty, arm robbery, street begging and other vices associated with poverty. Many developed nations have been pledged with what is described above. The aim of this study is to examine the five poorest countries of the world and their poverty reduction strategies adopted by their countries or leaders. The main contributing factors of poverty and their underlying effects were discussed in this study. The methodology used for collecting data was secondary source. The study concluded that there are some poverty alleviation strategies which, if adopted; it will make the achievement of poverty alleviation possible.

Keywords: poverty alleviation, poor nations, poverty line, absolute poverty, strategy.

\section{Introduction}

Poverty has been a major challenging issue that has eaten deep into the fabrics of most people in developing countries. This has been since known civilization came into existence. It is a widespread global problem that affects particularly the developing nations (Oshewolo, 2010). Poverty can be seen from the dimension of lack or premised on one's inability to have enough economic power to meet his/her own needs. As a consequence, these nations are unable to have and enjoy the basic things in life. This is because they are living below the poverty line which varies in time and places (Aline, Jesko, Hentschel \& Quentin, 2002). The poverty stricken nations are certainly an expression of what abject and total poverty is all about.

Due to poverty situation, people have been excluded from the development process, many are isolated, made powerless, helpless and frustration and depression set in. this eventually becomes a treat for health, human and property security and world peace in general. This phenomenon raises a global concern among leaders. This lead to the united nation millennium declaration adopted on $8^{\text {th }}$ September 2000 which is referred to as the Millennium Development Goals (MDGs), aimed at eradicating poverty by the year 2015 (Yekini, Rufai, Adeloba, Akinwole \& Ojo, 2012).. In the light of the above, policies were made and strategies were adopted and programs implemented. Although, causes of poverty differ from country to country, they may involve many inter-related factors. Therefore, Countries are expected to draw up policies and strategies to fit into their peculiar problems with due consideration to MDGs objectives.

\section{Literature Review}

\subsection{Concept of poverty}

There is no generally agreed acceptable definition of poverty. This is as a result of its multi-dimensional nature. In addition, there is the difficulty of deciding how to draw the line between the poor and the non poor. Aluko (1975) defined poverty as the lack of enough access to basic necessities of life. In another word Poverty is defined as inadequate 
consumption expenditure due to insufficient food, shelter, clothing, and schooling. Hence, the inability to participate actively in activities in the society (Kato \& Kratzer, 2013). Poverty in under-developed countries as conceptualized by Ogwumike \& Ekpenyong (1995) is the inability of the households' to provide enough income to satisfy its basic needs for shelter, clothing, food, education and transportation. The measurement for food is based on nutritional requirement in terms of calories and protein eating habit. Education and shelter are measured by the figure of children going to school, and their level of education and lastly, the number of person in a room. Clothing is measured by access and the number of cloths.

Duddley (1975) opined that the basic needs expect every community to provide for its citizens things like food, education, health, clothing, work and mobility. Steward (1985) asserted that there is a lack of reporting on basic indicators most especially in child mortality, diseases and mobility. In addition, there is the lack of enough income to satisfy the basic foods needs talk less about meeting basic services, and that there is positive urban bias in government expenditure for basic services. In conclusion, therefore, World Bank (1990) poverty was seen as the inability of an individual to attain a minimum standard of living.

\subsection{Types of poverty}

The types of poverty are:

Weiss and Montgomery (2004) classified the types of poverty, according to the length of time, i.e., chronic poverty and transitory poverty. Chronic poverty means those who have been in poverty for a very long time. This type of poverty can further be differentiated according to those who are physically advantage and those who are physically disadvantaged, that without welfare support they will continue to be in poverty. In addition, this type of poverty could be permanent. Transitory poverty means those who found themselves in poverty unexpectedly within a short period of time, due to adverse shocks. This type of poverty could be temporal.

Zaman (2000) considered the types of poverty in terms of land ownership. These are; ultra poverty which means a condition where people are having not up to ten decimal of land. Moderate poverty means people with more than ten decimals of land.

In addition, Oshewolo (2010); World Bank (2000); Rocha (1998) and Bradshaw (2006) concluded that poverty is in two types. The absolute poverty and relative poverty. Absolute poverty means inability to attend a minimum standard of living or poverty line (Oshewolo, 2010). World Bank (2000) described it as a state of life which encompasses sicknesses, deprivation and squalor. It is also a poverty situation when people cannot obtain adequate resources (measured in terms of calories or nutrition) to support a minimum level of physical health. This type of poverty can be eradicated. Relative poverty has to do with lack of equal support or opportunities and refusal to allow the poor access to the means of living (Rocha, 1998 Bradshaw, 2006). In other words, relative poverty can be seen as when people do not enjoy a certain minimum level of living standards as determine by government and enjoyed by the bulk of the population. This also differed from country to country or even within the same country.

\subsection{Causes and factors affecting poverty}

The factors that cause poverty, according to Schiller (2004) are as follows:

Low income: labor earnings are the main sources of income for most of the families. The total family income usually distinguishes between which families are poor and which of the families are not poor. Many of the poor people are unemployed or unable to find a job. Some of them work for part time at a skill level below their capability. Frustration associated with job search may so discourage job seekers that they stop looking for work (Grosso \& Smith, 2012). Majority of the poor families rely heavily on income transfers, welfare benefit such as food stuffs, cash, housing subsidies provide a quarter of the total income of poor parent families. These benefits provide half of the total income of poor female headed families.

Age and illness: most people are always poor because of their age, which hinders them from performing any activity that can change their economic status. Similarly poor people are more disposed to illness. Illness represented a sudden loss of economic well-being. Even for those who are driven to poverty for the first time by age or illness, the loss of economic status is occasioned by a variety of forces, none of which is inseparable from the natural process of aging and illness (Pramanik, Haneef, Meera \& Yusoff, 2008). Even though age and illness do not explain a high proportion of poverty, there are indefinable subgroups for which the causal link is particularly threatening. Among the aged, the most vulnerable to poverty are the old people who are of the risk of exhausting their financial resource and confront increasing health problems. 
Family size and structure: the most important features of poor people are the larger size of the families and broken families. About $30 \%$ of the poor people are from the families with above five members. While, nearly $40 \%$ of poor people are from one parent (Schiller, 2004). Many of the later are also from large families. There exist strong assumptions that family size and structure are important causes of poverty. This is particularly true of unmarried teenagers who are producing increasing teenage births and are most likely to become permanently poor and dependent. In addition, must traditional family structure also contributes to intergenerational poverty.

Culture and race: poverty causation theories based on culture and race has long commanded certain popularity. Poverty based on culture and race is based on the prejudices of the non-poor against the poor. They are based on the confidence that the non-poor perceive economic opportunity to exist for all. Conclusion drawn from the study showed that the lower class is a smaller part of the population of poverty and that its behavior is shaped by external forces than inbred cultural conflict (O'connor, 2000). Allegation about racial, disability suffers misunderstanding and prejudice. It does not make sense if we conclude that differences in smartness exist between the white and the black.

Lack or low level of education: individuals who have a high level of education tend to earn more than individuals with less education level. In addition, people who have a valuable ability tend to earn greater income (Azam, 2011). Education operates as a powerful mechanism in determining the distribution of poverty. Investment in human capital such as investment in education will increase productivity and income (Chaudhry, Malik, Hassan \& Faridi, 2010). Level of education is an important indication of motivation, commitment and ability. The relationship between ability and poverty are also more complex than expected. There is no sound basis for declaring that the poor are less fortunate because we do not have a clear definition and measurement of innate ability. This kind of observation means only that the poor make less money. Even when confined to measures of performance, such as IQ, the relationship of ability to income is oblique (Hirsch, 2007).

\subsection{The effect of poverty}

Poverty damages, where it damages childhoods, it damage life chances and the society. The effects of poverty are usually interrelated so that one problem hardly ever occurs alone. For example, bad sanitation makes it easier to spread existing and new diseases. Hunger and lack of water make people more exposed to poverty. Poverty stricken communities often suffer from diseases and finally end up caught in the cycle of poverty (Cliffs, 2014). The followings are some of the effect of poverty as opine by Poverties (2011) and Cliffs (2014):

Effect of poverty on the society: the life long trouble and handicaps that are passed on from one generation to another are so called cycle of poverty as mentioned before. Few of these innate plaques are lack of education facilities, children go to work in order to help their parents, lack of basic hygiene and transmission of diseases. Unemployment and very low pay among parents create a situation where their kids are unable to go to school; they just don't see how hard work can improve their life as they see their parents fail at a daily task. In the end, poverty is a major ground of social tensions and threatens to divide a nation because of the issue of inequalities particularly income inequality. This happens when wealth in a country is not well distributed among its citizens. In other words, where a tiny minority have all the money. The features of rich or developed countries, for example, is the presence of a middle class, but, recently we have seen even the western countries are gradually losing their middle class, hence the increasing number of riot and clashes. In a society, poverty is a very harmful factor that can destabilize the entire country. Hence, there will be a lack of intelligentsia and educated intellectuals to run the country and therefore poverty issue will remain (Poverties, 2011). Besides that, poverty can also cause high infant mortality and annual death rate, increase crime rate since people turn desperate to survive in the face of poverty and increased rate of homeless people. Moreover, poverty leads to increase in hygiene and diet related diseases, for example cholera, dysentery, tuberculosis.

Effect of poverty on children: children who grow up in poverty suffer more persistent, frequent and severe health problems than do children who grow up under better financial circumstances. Many infants born into poverty have a low birth weight, which is associated with many preventable mental and physical disabilities. Not only are these poor infants are more likely be sick, they are also more likely to die before their first birthday. Children raised in poverty tend to miss school more often because of sickness. They have more tendency to engage in an accident than other children and they are twice as likely to have impaired vision and hearing, iron deficiency, anemia and higher than normal levels of lead in the blood, which can impair brain function (cliffs, 2014).

Effect of poverty on women: meaning of feminization is poverty is part of women in the world and that poverty is becoming a problem and affects the women more than men. Mostly in developing and developed countries, there are social and cultural biases against women. Women are not allowed for any higher position and girls are not given proper education because many parents prefer investing in their boys. As a result, most women are unemployed because of 
poor education background Curran (2003). Besides that, the one child policy in china increases the number of missing women. The families kill or abandon newborn baby girls and hope to have a boy because boys seem to have social status. Moreover, women in poverty die giving birth and most of them suffer from preventable diseases because of lack of hygiene and safe drinking water (poverties, 2011).

Effect of poverty on terrorism: it has become a common headline in newspapers to blame poverty of fueling terrorism by creating a state of misery and frustration that pushes people to join terrorist organizations. While, this doesn't seem a totally groundless accusation- it makes sense and feeds the riches' tormented conscience. It is important to note that most at a time terrorist do come from the poorest countries with high unemployment. While, the terrorist organizations often provide much higher salaries than any other jobs, if any other jobs are available at all. Infact a lot of different factors interact with the decision to become a terrorist. Personal and cultural ideas and principles are just as important as material and social gain (reputation \& fame for fighting the imperialists) of entering terrorism (poverties, 2011).

\subsection{Poverty alleviation strategies adopted by five poor countries in the world.}

Poverty alleviation strategies are step taken to develop and carry out activities to reduce poverty by member countries. The meeting usually takes the form of consultation with its stalkholders and other development members such as the World Bank and International Monetary Fund (Aline et al., 2002). The main expectation at the end of this consultation is for member countries to go and direct their own development agendas, policies and programs to fit into their peculiar problems. Based on the aforementioned statement, it then means that countries could have different strategies, but may also borrow workable and successful strategies from other countries.

Poverty reduction is one of the most difficult and serious challenges facing most developing countries. It was figured out as one of the challenges facing humanity, this was the main issue discussed at the fourth world conference on women in Beijing 1995. Efforts to deal with poverty will have to start with the relevant variables related to poverty as outlined by Rana Assad in the poverty reduction strategy paper. They are low level manufacturing and value added, constraints to agricultural productions and productivity, underdevelopment of eco-tourism, poor governance, insecurity, corruption, lack of accountability, discrimination, to mention but a few (Human Development Report, 2003). The strategy to boost the standard of living of the poor need to be focused and oriented on the genesis of the causes and not just on the symptoms. Below are the strategies of the five poorest countries of the world to address poverty.

\subsubsection{Niger}

The following strategies are adopted:

- Macroeconomic and financial stability of the poor

- Development of productive sectors especially in rural areas.

- Implement an access to the poor quality social services.

- Straitening of institutional and individuals' capacity within and outside government at central and local levels. (International monetary fund, 2008)

\subsubsection{Uganda}

The following strategies are adopted:

- Creating a framework for economic growth and transformation.

- Ensuring good governance and security.

- Directly increasing the ability of the poor to raise their income.

- Directly increasing the quality of the life of the people.

(Ministry of finance, planning and economic development Kampala, Uganda, 2000).

\subsubsection{Congo}

The following strategies are adopted:

- Improvement of governance and consolidation of peace and security.

- Promotion of growth and microeconomic stability. 
- Improvement of public access to basic social services.

- Improvement of the social environment and integration of disadvantaged groups.

- Combating HIVIAIDS.

(International monetary fund, 2012)

\subsubsection{Liberia}

The following strategies are adopted:

- Expanding peace and security.

- Revitalizing the economy.

- Strengthening governance and delivering basic services.

(Liberia poverty reduction strategy, 2012).

\subsubsection{Zimbabwe}

The following strategies are adopted:

- $\quad$ Facilitate pro poor policy dialogue and formation of national level through strengthening of MDGs based policy formulation, planning, monitoring and reporting at all levels.

- $\quad$ Continue to support the MDGs-based national poverty reduction strategy Zimbabwe Economic Development Strategy (ZEDS).

- Enhance the integration of gender and HIV and AIDS into to the national development policy frameworks through the national budget and all sector strategies and policies.

- Promote and advocate the human development paradigm through support to the regular production of National Human Development Reports (NHDRs) on contemporary thematic issues.

- Strengthen national information systems for MDGs-based and evidence-based policy formulation and development planning in order to develop a comprehensive poverty monitoring system. This will include support to the transformation of the central statistical office (CSO) into an autonomous National Bureau of Statistics.

- $\quad$ Support community based livelihoods recovery programs and vocational skills training.

- $\quad$ Support dialogue between government, Civil Society Organization (CSO), labor, business and the community towards consensus building on macroeconomic development challenges facing the country.

- Support the formulation and implementation of policies and regulation supportive of strong macroeconomic frameworks, equitable trade and sustained growth led by effective public-private sector partnerships.

- Support capacity building for skills development and retention and institutional building for and efficient service and the public sector.

- $\quad$ Support land and agricultural development as a pillar for sustained poverty reduction within this predominately agro based economy.

(United Nations Development Program, Zimbabwe, 2011).

\subsection{Suggested ways member countries can adopt to alleviate poverty}

The ways suggested to the countries engulfed by poverty to reduce it is as follows:

Increase productivity and valve addition: increase productivity and valve addition in agriculture, self-reliance in commodities and food security through better production of crops and livestock development can help income creation and improve household income. Workshops to learn new innovations and methods can be conducted (Anderson, 2012). Agriculture provides a safety net for jobs and economic bumper where other sectors are battling to stand.

Protecting the poor and the vulnerable: the poor and most vulnerable (women and children) in the society can be protected from the basic element of extreme lack. Provision of direct employment can be made and also subsidy on food and other basic necessities of life to help alleviate poverty. Funding of specific safety programs may be embarked upon by government of such countries. Provide health care services, clean drinking water and sanitation services, infrastructural facilities for the people, unmet educational expectation of the people should be bridged.

Land liberation: property right should be given to the poor. In one of the World Bank report Fareed (2008) it is expressed that giving land right to the poor will go a long way to reduce poverty. This is because the land right will greatly increase wealth to the poor. In line with this, it was also observed that in China and India, the poverty level reduced in 
recent years as people abundant collective farming for individual work. Securing property rights to land is a great assets to most communities for economic freedom. This will allow the poor to increase wealth for themselves.

Trade freedom: liberation in trade can buffer total surplus of the trading nation. Giving the home industries the chance to be internationally competitive will encourage the private sector to be involved in all spheres of the country's economy and thereby improving its foreign investment to make the economy to grow faster. Trade regulations are sometimes very rigid and unhealthy as they block access to richer nations market and ban poorer nation's from being supported. Poverty may be reduced by creating and improved business environment which provides a favorable podium for proper economic activity.

Opportunity for self sufficiency: government can design businesses with social goals in mind. Polak (2008) opined that creating companies to employ the poor is a very good strategy. Manufacturing goods and proving them as at affordable rate is excellent. This he did not opined but practices. In the same vein, Singer asserted that if only each of the affluent nations can make a little change in the ways they live their lives; it will solve the world poverty problem.

Employment and productivity: increase in job opportunities is expected to go hand in hand with productivity. This is because the increase in employment without an increase in productivity will only among to increase in the workers number of the poor. Every possible avenue should be explored for creating job opportunities. Farmers can be supported by providing them subsidizes on seedlings, farm implements, improve water management (Chaudhry et al. (2010), technology in farming. Microfinance banks may make a difference by giving loans to those who wish to be self-employed and provide jobs for the poor.

Climate change adaptation: Melamed, et al. (2011) suggested that poverty reduction should be merged with climate change. The World Bank report of 2008 also made the same recommendation. This is due to the devastating effect of changes in the environment which is having a negative impact on the people flora and faunas. All these strategies which centers on expanding economic and job opportunities, facilitating access to basic economic and job opportunity by the underprivileged, providing increased access to basic health service and humane development, commercial services, infrastructure and extension services is not adequate. A strong implementation and monitoring strategies need to be put in place.

\section{Conclusion}

This paper looks at assessing what poverty is and what strategies are being adopted by some few poor nations to address the poverty situation of their citizens in their various economies. Poverty is considered as the inability of a nation to provide for its citizens basic needs that will guarantee a minimum standard of living. Therefore, the poor nation needs to develop strategies to reduce the poverty level of their citizens.

The paper found out that the strategies formulated by the member nations most especially the poorest nations are not being implemented and followed strictly and more so, fund allocated are misappropriated. That is why poverty is still visible in these nations, despite the strategies adopted. Therefore, the paper suggested that a proper monitoring team comprising of credible people is put in place. Poverty alleviation strategies should aim at removing social and legal barriers. Otherwise, countries will continue to remain poor in spite of resources and strategies that have been proposed to alleviate poverty.

\section{References}

Aline, C. Jesko, S.H. \& Quentin, T.W. (2002). Poverty measurement and analysis. in Jeni K. (ed.), a sources for poverty reduction strategies, Washington DC. The World Bank. http://povlibrary.world bank.org/files/5467_chap1.pdf. Accessed May 20, 2013.

Anderson, R.D. \& Muller, A.C. (2013). Competition policy and poverty reduction: A holistic approach. http://www.wto/english/ res_e/reser_e/ersd201302_e.pdf. accessed June 17, 2013.

Aluko, S. (1975), "Poverty: Its remedies" in Poverty in Nigeria. The Nigerian Economic Society, Ibadan.

Azam, M. (2011). Causes and measurement of poverty reduction in Pakistan. Interdisciplinary Journal of Contemporary Research in Business, 2(11), 76-83.

Barnard, H. \& Turner, C. (2011). Poverty and ethnicity: a review of evidence. http://www.jrf.org.uk/sites/files/jrf/poverty-ethnicityevidence-summer.pdf. accessed May 30, 2013.

Bradshaw, T.K. (2006). Theories of poverty and anti poverty programs in community development. RPRC Working Papers 05-06.

Bugger, C.W. (2007). World Bank report puts agriculture at core of anti poverty effort. The New York times. http://www.nytimes.com/ 2007/10/20/world/africa/20worldbank.html?_r=0. Accessed June 15, 2013.

Chaudhry, I.S. (2009). Does education alleviate poverty? Empirical evidence from Pakistan. International Research Journal of Finance and Economics, 23(1), 24-32. 
Cliffs N. (2014). Causes and effect of poverty. Houghton Mifflin Harcour., http://www.

Cliffsnotes.com/science/sociology. Accessed September 9, 2014.

Curran, L. (2003). The culture of race, class and poverty: The emergence of cultural discourse in early cold war social work. Journal of Sociology and Social Welfare, xxx(3), 15-39.

Doyle, M. (2006). Can aid brings an end to poverty? BBC. http://news.bbc.co.uk/2/hi/africa/5407770.stm. accessed June 20, 2013.

Dudley, B. J. (1975), "Power and Poverty" in Poverty in Nigeria: Proceeding of the 1975 AnnualConference of Nigerian Economic Society.

Fareed, Z. (2008). How to save the world. The Newsweek, http://www.thedailybeast.com/newsweek/2008/09/19/how-not-to-save-theworld.html. accessed may 15, 2013.

Grosso, J.L. \& Smith, T.L. (2012). Poverty and unemployment: A cultural approach. Thunder Bird International Business Review, 54(1), 79-90.

Hirsch, D. (2007). Experience poverty and educational disadvantage. Joseph Rowntree foundation.

Human Development Report (2003). A compact among nations to end human poverty. UNDP.

IMF (2012). Republic of Congo: Poverty reduction strategy. National Development Plan. http://www.imf.org/external/publication. accessed June 5, 2013.

Kaka, E.J. \& Abidin, F.Z. (2013). Poverty is a woman issue in Africa. IOSR Journal of Humanities and Social Science, 18(6), 77-82.

Kato, M.P. \& Kratzer, J. (2013). Empowering women through microfinance: Evidence from Tanzania. ACR Journal of Entrepreneurship Perspectives, 2(1), 31-35.

IMF (2012). Liberian: poverty reduction strategy paper-annual progress report. International Monetary Fund Annual Report 12/45.

Melamed, B.C., Hartwig, R \& Grant, U. (2011). Jobs, growth and poverty: what do we know, what don't we know and what should we know. Oversea Development Institute, www.odi.org.uk. Accessed September 9, 2014.

O'Connor, A. (2002). Poverty research and policy for the post-welfare era. Annual Review of Sociology, 26(1), 547-562.

Ogwumike, F. O. and Ekpenyong, D. B. (1995), Impact of Structural Adjustment Policies on Poverty and Income Distribution in Nigeria. Final Report to the African Economic Research Consortium (AERC) Nairobi Kenya

Oshewolo, S. (2010). Galloping poverty in Nigeria: An appraisal of the government interventionist policies. Journal of Sustainable Development in Africa, 12(6), 264-274.

Polak, P. (2008). Out of poverty: What works when traditional approaches fail. Berrett Koehler Publisher,

Poverties. Org. (2013). Causes and effect of poverty on society, children and violence. Research for Social and Economic Development.

Pramanik, A.H., Haneef, M.A., Meera, M.K. \& Yusoff, W.S.W. (2008). Poverty with many faces: A case study of Malaysia. (1st ed.), IIUM Press.

Rocha, S. (1998). On statistical mapping of poverty: Social reality, concept and measurement.

Background paper prepared for the expert group meeting on poverty statistics, Santiago, Chile, May 9.

Schiller, B.R. (2004). The economics of poverty and discrimination. (9th ed.), Pearson Prentice Hall.

UNDP (2010). Zimbabwe Millennium Development Goals. Status Report. www.undp.my/content/dam/undp/.../zimbabwe/

Weiss, J. \& Montgomery, H. (2004). Great expectation: microfinance and poverty reduction in Asia and Latin America. ADB Institute of Research Paper Series 63.

World Bank (1990). Poverty World Development Report. Oxford University Press.

World Bank (2000). Poverty in the age of globalization. Washington DC. www.sph.umic.edu/symposium2004/pdf/poverty/globalization. pdf. accessed April 7, 2014.

Yekini, N.A., Rufai, M.M., Adetoba, B.T., Akinwole, A.K. and Ojo, O. (2012). Ict "tools" for poverty eradication and economic growth in Nigeria. Grenner Journal of Educational Research, 2(1), 013-019.

Zaman, H. (2000). Assessing the poverty and vulnerability impact of microcredit in Bangladesh: a case study of BRAC, World Bank, Policy Research Working Paper. 